\title{
Making a Case for An Integrated Faculty-Designed and Faculty-Operated Study Abroad Center
}

\author{
Sarita Rai \\ University of Hawai 'i at Mānoa, United States \\ Email: sarita@hawaii.edu \\ Address: Study Abroad Center 1890 East-West Road Moore Hall 115 Honolulu, HI 96822, USA
}

\section{Introduction}

Study abroad matters. This might seem to be a very simple statement, but ensuring that study abroad matters is actually complicated and difficult. Using the University of Hawai'i Mānoa Study Abroad Center as a case study, this essay argues that in all areas of programming and functioning, a viable Study Abroad Center must involve faculty from all areas of the institution. Having faculty members with an active stake in Study Abroad is, indeed, the single most important way to bring about positive outcomes and to sustain them in both the short term and the long term (Giedt et. al. 2015, 173; Gose 2018, 1-3). The problem is that many factors are at work, and high-level administrative officers do not always view the Study Abroad Center as an academic unit with academic commitments. They tend instead to see it as a way to elevate and publicly show the international standing of the institution (Eaton, et. al., 2013). For example, the annual survey of study abroad and international programs compiled by Open Doors ranks schools according to their total number of participating students ("Leading Institutions"). These types of data can be highly effective tools for universities' recruitment purposes. Looking beyond the number of participants, this paper focuses on a more subtle and important factor: that of shared governance. Consequently, I argue here that positive outcomes for students depend on shared governance, and the key to shared governance is participation by faculty. In other words, two crucial aspects of a thriving Study Abroad Center are high faculty involvement and shared governance.

\section{Contexts}

The Study Abroad Center of the University of Hawai' $i$ is an integrated faculty-designed and faculty-operated center. In operation for over three decades, its system may be particularly useful for faculty or administrators who want to know how other institutions have created and sustained programs with high faculty involvement. It is fairly safe to say that faculty initiatives are not always the top priority of senior international officers and that top-down communication can be problematic. Kellie Woodhouse, for example, looks at this issue, and foregrounds effective communication as a sign of healthy shared governance and a healthy institution. She discusses numerous places, including Harvard University, the University of Michigan, King's College in Pennsylvania, and Creighton University, where faculty have protested or were at odds not just with senior officers' proposed budgets but how those plans were communicated from administration down to the academic units and faculty organizations (2015, n.p.). These and other examples that Woodhouse provides illustrate how nonacademic, upper-level management often focuses on increasing student enrollment and on prioritizing revenues coming into the school (also see Eaton et. al. 2013; Ehrenberg 2000; Slaughter and Leslie 1997). Virginia Horvath, President of SUNY Fredonia since 2012, explains that priorities such as these develop as colleges and universities "are challenged to operate under greater external scrutiny, with expectations of compliance with shifting state and federal policies, and demands for efficiencies in all operations." Her co-author, Rob Deemer, cites ten reasons that the sharing of responsibilities is "rarely modeled or encouraged" in academia (2), and among those reasons is the influx of officers and board members who come from corporate environments (Deemer 
and Horvath 2017, 22-30). Larry G. Gerber echoes this position. He argues that corporate-based assumptions about "readily quantifiable bottom-line "outcomes"" and emphases on accountability and assessment are too often used primarily to justify receiving continued funding (2004, 166-67). Success, however, for study abroad programs run by a faculty director whose foremost priority is academically rigorous programming is more likely to be gauged in terms of 1) appropriate curriculum for students needing to fulfill requirements and make progress in their major fields, 2) meeting learning outcomes that measure students' international competencies, 3) enabling faculty to conduct scholarship, research, and course development based on their teaching assignment along with service and scholarship that keep them on track toward tenure and promotion, and even more broadly 4) creating international multi-institutional collaborations. José Antonio Torralba details this in the context of developing service-learning partnerships with schools and local agencies in host cities (55-62). When accomplished, even in this individual area, the results can have an enormously positive impact on all levels of an institution. Meeting them contributes to long-term morale, student retention and graduation rates, and to the international reputation of the institution. Meeting all of these goals is ambitious, but with strategic planning and perseverance, it can be done.

\section{Methods}

The ideas in this article emerged during a project from 2010 to 2018 that involved research, writing, and editing and which led to a volume of essays published in 2019. That project, both collaborative and multidisciplinary, involved working with research partners and contributing authors from disciplines ranging from international education to mathematics, sciences, and the liberal arts. The essays in the volume were intended to be, and are, expository and informational rather than rhetorically argumentative or controversial. In contrast, this article demonstrates the stakes that underlie curricula and policies of study abroad programs. My position here is, therefore, thesis-driven and meant to encourage ongoing debate about the role of shared governance in higher education. To this end, I rely on contemporary and recent scholarship in international education, higher education, university structures, and study abroad. I also use an instrumental case study of a large public university, one where I have directed a highly diverse study abroad program for over twenty-five years. Well aware of the limitations, I have chosen to describe and analyze this single case because it offers a vivid picture of the dynamics and pressures that occur over time, especially as senior officers come-and-go and upper management works to implement new policies and procedures. The case-study approach here draws particularly on research whose focus is the history and evolution of study abroad opportunities provided by U.S. postsecondary institutions. Finally, the article seeks to showcase the dynamics of a shared-governance model for study abroad programs and to offer perspectives for specialists whose job is to initiate and sustain Study Abroad programs in the twenty-first century.

\section{A Case Study and Implications}

Founded in 1907, The University of Hawai 'i at Mānoa is a land, sea, and space grant research-intensive university. This means that the school is obligated to teach curricula that cover agriculture, earth science, ocean studies, and space research along with other disciplines offered at a comprehensive institution of higher education. It therefore awards bachelors, masters, and doctoral degrees across nine colleges and nine schools (manoa.hawaii.edu/academics/colleges/). The University of Hawai'i at Mānoa, in Honolulu, is the flagship campus of a ten-campus system that includes community colleges and two four-year colleges. The system has professional schools, research facilities, and community-based learning centers. Total enrollment is approximately 51,674 students ("About the University," 2019). State funds form 44 percent of its income (“Annual Financial Report," 2019), which is substantial in comparison to other large public U.S. universities (Seltzer 2018). The University promotes international 
research in many disciplines. International activities are central to the institution's formal mission statement. Nonetheless, state funding from the Hawai'i State Legislature has gradually diminished.

There were attempts through the decades to build a study abroad program, and as happens in other institutions, establishing long-term personnel was difficult. But in 1979, the Director of International Students under the auspices of the Student Affairs Office was given the responsibilities to make study abroad available, and, in the late 1980s, the Hawai'i State Legislature clarified its commitment to internationalization of the university. It created two full-time, tenure-track faculty positions for individuals to organize and run a program that would be viable for both students and faculty. These two faculty appointments, requiring advanced degrees and allowing for individuals to come up for tenure and promotion, were and remain today unusual in postsecondary institutions. The decision was likely due to the Board of Regents' policy regarding multiple classifications of faculty eligible for tenure. For example, in addition to "I" faculty for instructors, there are "R" faculty for researchers, "S" faculty for specialists who develop and administer academic programs, and "E" faculty (extension agents) who work primarily in the community (Board of Regents, 2018). Not many Study Abroad offices can claim similar positions for administrators contractually to engage in academic activities and research, but my purpose is to illustrate the possibility of a best-case scenario when Study Abroad has continuous support and collaborative advocacy.

The location of study abroad within the administrative structure of a university is generally a reliable indication of how its purpose is understood by senior officials (Rai 2019, 144-156). In accordance with the history and development of the institution, the office will likely operate under the aegis of student services or else under academic affairs. Students need to receive good counseling wherever the office is placed, so it behooves study abroad personnel to be knowledgeable about the structure of their institution and to work within the limits of what they understand will be feasible. To be sure, many universities have Study Abroad programs operated by an Office of Student Affairs (DeYoung and Primak, 2010, 18-19). But in larger terms, this means that a nonteaching unit, without faculty affiliations or direct participation by departments or academic divisions, finds ways to send students abroad and receive credits transferred from a host institution. Such credits may or may not be accepted by new department heads, and these credits must always be approved on a one-to-one basis, a process that can take considerable time and leave students in academic limbo. Home institution instructors do not necessarily accompany students to the host institutions or third-party provider sites. Students with academic, emotional, or health problems may be left to fend on their own, and if they find an appropriate site administrator or adviser, that person may not be able to offer help as quickly or for as long as the students need. Melissa Morgenstern, a translator/journalist who studied in China, writes that it is "surprisingly common" for students to experience depression or anxiety due to the "unexpected or underestimated challenges of diving head first into a new language and/or culture" (2018, n.p.). She advises students to know beforehand the benefits of their medical insurance, but as happened in her own case, pre-orientation counseling can get lost in the midst of other priorities. She cautions also that finding host school therapists or private professionals can take time, be limited in availability, and be subject to local laws and restrictions. Apart from these academic and personal counseling issues, the institutional affiliations with the international locations may be thin. Though faculty may be encouraged to organize individual study tours with their students, these are most often on an ad hoc basis and for short periods of time. This is especially the case in the third-party provider model, which does not facilitate collaboration among the participating schools. And most crucially, students who go abroad leave their home school without assurances of mentoring, appropriate advising, or an academic program with the same quality as their home institutions.

With potential lessons for other programs, the Hawai'i Study Abroad Center demonstrates that even in a best-case scenario, maintaining academic emphases can be a challenge. This is true even when Study Abroad is state-mandated as a comprehensive, university-wide office with permanent positions. Here is some history: In 1993, it became clear that being situated in the Office of Student Affairs was not an appropriate alignment for the Center. The faculty wanted a different model, and they made their case. They formed a group called the Study Abroad Advisory Committee, which 
advocated for a Center that functions with the cooperation of academic departments and colleges, and the group's efforts were successful. As a result, the Study Abroad Center was removed from the Office of Student Affairs and into the Office of Academic Affairs. This shift would not have happened without the urging of faculty. Activist in nature, the instructors understood studying abroad to be an academic matter. They wanted to ensure high-quality opportunities that were appropriate for their students. Simply put, studying abroad became an academically contextualized program under the direct purview of the Vice President of Academic Affairs. Access to a Vice President came along with the move and gave dramatic momentum to the Center's reputation and programming opportunities. The Director, who is also a faculty member, can innovate and launch new programs in consultation with faculty and students, who believe that certain curricula will enhance their education. The concept of shared governance and faculty governance is easier to support than the actual practicing of it, but the Study Abroad Center relies heavily on just that practice. As Gary A. Olson writes in the Chronicle of Higher Education (2009), "Shared' governance has come to connote two complementary and sometimes overlapping concepts: giving various groups of people a share in key decision-making processes, often through elected representation; and allowing certain groups to exercise primary responsibility for specific areas of decision making (n.p.).

\section{Specific Examples of Shared Governance}

Scholarship indicates that shared governance is the subject of ongoing dialogue in the profession. Numerous recent studies look at the advantages, disadvantages, and challenges for all of the involved constituencies. Larry G. Gerber's The Rise \& Decline of Faculty Governance: Professionalization and the Modern American University recounts the history of shared governance in higher education and presents various perspectives on best practices for the future management of U.S. colleges and universities (2014). Sharon F. Cramer's two volumes of essays by distinguished contributors Shared Governance in Higher Education: Demands, Transitions, Transformations (2017) and Shared Governance in Higher Education: New Paradigms, Evolving Perspectives (2017) are comprehensive books for all individuals impacted by current discussion on the collaborative processes fundamental to shared governance. William G. Bowen's and Eugene M. Tobin's Locus of Authority: The Evolution of Faculty Roles in the Governance of Higher Education (2015) uses four case studies to consider when trying to find the most effective decision-making strategies in the contexts of academic freedom and organizational hierarchies.

At my own university, important instances of shared governance for Study Abroad begin with a multidisciplinary Advisory Committee that advocated in the early-1990s for an academically driven Study Abroad Center. The ideas discussed in that group evolved into what is now called The Council on Study Abroad, and the Council's ongoing role exemplifies how various groups of people collectively make key decisions. This Council consists of fourteen members, one of whom is ex-officio (Study Abroad Director). Council members, who are appointed by the Faculty Senate of the University, collectively bring to bear diverse academic expertise; currently they represent departments or schools of French, English, Asian Studies, Social Work, Civil and Environmental Engineering, Business, Hawaiian Studies, Food Human Nutrition and Animal Sciences, Political Science, Law, Nursing, Physics, and Plant and Environmental Science. The Council's fundamental charges are to recommend policy and advise on proposed programs in terms of feasibility and academic quality. The Council appoints Study Abroad Resident Directors and collaborates with Program Review committees to evaluate the Center's offerings in conjunction with periodic five-year program reviews. Additionally, the Council functions as the curriculum committee of the Study Abroad Center, choosing varied and inventive course proposals by faculty applicants that reflect the study abroad location (students also take courses with the host school professors). Recent offerings chosen by the Council on Study Abroad include "Berlin and the Digital Music Era," "Art \& Lies: Popular Fiction about Art in Paris." "Physics in Florentine Art," and "Survey of the Sociology of Aging in Japan." In all these ways, the Council ensures that the Mission of the Study Abroad Center is achieved. It also ensures that course offerings differ from year to year, aiming for diversification of content and 
disciplines. As deWinter and Rumbley write, the increases in the number of selections in study abroad "have required greater involvement on the part of the faculty in the design, management, and assessments of the programs" (2010, 103).

Given the serious responsibilities of the Council on Study Abroad, it is worth pointing out its role in selecting individuals to teach in our programs. The Council makes its selections from an applicant pool for every country and every semester. The application process is competitive, with slots available to faculty in all disciplines and departments. While a number of programs exist that emphasize language instruction, most of them include elective language study but offer courses in many subjects represented by the Council's members. The Council's decisions are by majority vote, and members are free to consult with the Director, when necessary. The Director then implements Council policy and makes the operational and logistical decisions.

Study abroad offices elsewhere may or may not have faculty directors, but a full team of faculty and administrators working in a shared governance capacity is crucial to sustain faculty support, advocacy, and program legitimation. Krawutschke and Sideli recommend this full-team approach for implementation and legitimation of overseas programs (1993, 27-28). Indeed, they cite a National Task Force Report that recognized this necessity early on and that gave the lack of institutional commitment as the first of seven factors that can stand in the way of expanding and improving studying abroad (1993, 269-70). In very specific terms, faculty enthusiasm and support of study abroad has meant for us a seamless working relationship with home-based academic divisions that ensure academic integrity and credit articulation. It is largely faculty governance that allows our students, wherever they go abroad, to fulfill major, general education, and graduation requirements. There are a few departments that give students added options for study abroad, but the Study Abroad Center is the only unit that provides programming and curriculum to the entire student body.

\section{The Business of Study Abroad}

It is no secret that private and public postsecondary institutions across the country are being corporatized. Some schools may be affected more than others, but essentially this means that upper management has been organized and reorganized according to corporate structures (Bok 2004; DeBoer 2015). Universities are under pressure to adopt corporate models for their internal organization, and the result has been the emergence of a powerful managerial class. In international education and study abroad arenas, this has taken the form of positions such as international vice presidents, international provosts, assistant international vice provosts, and senior international officers. These officers may have been instructional faculty earlier in their careers, but they generally have far more experience in administration than in their original fields. Understandably, they come to measure success in terms of student numbers and revenues. Faculty and faculty administrators responsible to their departments and academic units, though, tend to give more priorities to curricula and academics. Budgets cannot be ignored, but they may not to be the very foremost consideration. While it could be argued that senior-level managers and their mid-level appointees bring practical knowledge into the mix of faculty governance, this may not always be the case. The idea of shared governance is not part of the corporate hierarchy, and may, in fact, be co-opted by top management. The corporate model, in contrast to the faculty governance or shared governance model, bars collaboration and seeks to maintain distance between management and individual directors, faculty administrators, and faculty instructors. Directives originate from the presidential or provost levels ultimately responsible to a Board of Regents. As Steven Bahls writes, many board members "tend to view shared governance as an obligation to consult with faculty before major decisions go forward" and use words such as "sign-off" and "buy-in" to characterize all that they want from faculty. Bahls adds that even board members who recognize that consultation with faculty can be very useful often still focus on "their right to retain ultimate control more than on their obligation to share governance in the most meaningful way" (Bahls 2017, 84-85). There is no conspiracy here, but rather two organizational models for postsecondary institutions. While again it could 
be argued that the two models provide a salutary mix of opinions that in the long run offers the best prospects for a healthy financial and academic future, the actual experience may be more complicated.

\section{Repercussions and Challenges-Study Abroad at Risk}

Like many other universities, the University of Hawai' $i$ system has undergone many reorganizations due to the emergence of both an academic managerial class and the corporatization of higher education. For the Study Abroad Center, the reorganizations have created distinct challenges. The insertion of an additional layer of management has been both political and politicized. The new managerial position that is most directly relevant to my work as the Director of the Study Abroad Center is the position of an Assistant Vice Chancellor in charge of International and Exchange Programs. The nomenclature might seem benign, but the stated responsibilities reveal something else. The single position is actually a dual one, because the person serves two jobs: halftime as Dean of a College and halftime as Assistant Vice Chancellor for International and Exchange Programs, reporting to the Vice Chancellor for Academic Affairs. This Assistant Vice Chancellor also oversees five offices that, again on first glance, appear to be related but actually have rather different constituents. These are International Student Services, Faculty and Scholars Immigration Services, International Exchange, National Student Exchange, and Study Abroad Center. As an ensemble, so to speak, we have comprised an entirely new unit since 2007 known as the Office of International and Exchange Programs.

Pulling these five offices away from their different original home base (from Student Affairs to Academic Affairs) has reverberated across the institution. Directors of each of these offices are in the process of gauging the new dynamic and determining if the benefits for them outweigh the disadvantages. My perspective of this collective grouping, based on our meetings with the new presiding officer, is that the disadvantages are considerable. The major disadvantage is that Study Abroad is under pressure to revert back to its pre-1990s position as a student services unit. There are two lessons here that are especially noteworthy with lessons for other Study Abroad directors. First, Study Abroad centers are always at risk. Directors have to pay attention to the comings-and-goings of administrators and senior officers, which, under the corporate model, may be frequent. It's not unusual for each officer to have a different vision from the previous officer and to try to reorganize the plan that is in place. Two, Study Abroad directors, wherever they are on the academic/managerial hierarchy, should assume that they will have to defend their units regularly, or potentially lose their academic status as the pressures for ever-increasing enrollments and revenues mount. My office has had a best-case scenario for personnel, relations with deans, chairs, and faculty, but we are now struggling to maintain what I see as our integrity, and my concern extends to my cohorts in the rest of the US.

The first area of particular concern is student safety - the most fundamental priority of Study Abroad. Like other universities with study abroad programs, risk management orientations are a mainstay of the program. My Center mandates that all students, on short summer programs as well as year-long stays, attend twelve hours of pre-departure cross-cultural and risk-management training. Faculty attend these twelve-hour sessions as well as additional sessions focusing on risk management at the program location. All these sessions are both comprehensive and detailed, presenting a wide range of contingencies and case scenarios. In the risk-management segment, faculty are trained to manage and document accidents and contact Study Abroad personnel (twenty-four hours a day); what local resources are immediate responders; elements of cross-cultural safety; and emergency procedures. Students learn whom to text, call, and email at the host school, in the town, up to the American Consulate. They know the first line of support and the crucial importance of letting family and us immediately know their whereabouts, after which we will contact other people both home and abroad and make all necessary arrangements.

In the twenty-first century, crises of national or international magnitude have to be taken very seriously. No one can predict the future, but Study Abroad directors are well qualified and prepared to make decisions regarding students' safety. Increasingly, directors are trained in health, safety, and risk management, and universities are providing more funding for specialists within Study Abroad who focus solely on health and security (Rhodes, et. al., 
2012). Many publications in the field are available, for example, Patricia C. Martin's Crisis Management for Education Abroad (2017), Gregory F. Malveaux's Look Before Leaping: Risks, Liabilities, and Repair of Study Abroad in Higher Education (2016), and NAFSA's Responsible Study Abroad: Good Practices for Study Abroad (International Organizational Task Force 2002). And in the unfortunate case of an accident or violence, enacting shared governance is crucial because it works in extreme conditions as well as in daily professional contexts. We are very familiar with our emergency protocols and procedures for natural disasters and for limited-scale and large-scale violence. We know how and where to gather highly specific information for making critical decisions that best serve the students in the long term and the short term. We initiate two-way communications with our multiple local contacts in the town or city where students are based; we do this automatically and rapidly. In my experience, top-down directives do not always take into account on-the-ground information. Doing so would require restraint on the part of senior management to wait for all the exigencies to be considered. For example, what transportation modes are operating? What local facilities are working? What, despite instantaneous media coverage, are the accurate details of the situation?

Directives issued by senior managers or vice presidents are at risk of being made in response to the press or general statements made on social media and news programs. I was Director of Study Abroad during the 1995 earthquake in Kobe, Japan; the 2011 Fukushima Daiichi nuclear disaster; the 2015 bombings in Paris; and the 2016 bombing in Brussels. Every horrific event is unique, but the protocols are always relevant. Contact with students and our local resources checked everyone's safety. Then we collectively discussed the options from remaining at the respective sites to immediate evacuation to the U.S.. Of course we used State Department bulletins and advisories, but the key element was our networks for gathering very specific information and developments. After our discussions, which included senior officers, we advised our students in Kobe to return home. We made the arrangements, and our on-campus faculty ties enabled the returning students to join classes already in session on campus and to consult with the professors on a reasonable course of study for the rest of the semester. Senior management collaborated in the decision but refrained from issuing a corporate mandate.

The case in Fukushima was different because the senior officer did issue an immediate mandate that our students evacuate. A nuclear power plant can pose very serious problems, and the news stations in Hawai'i were pressing hard for statements from senior managers who have public visibility. The directive for evacuation went out even as our contacts on the ground and our Resident Faculty Director there were explaining that, thankfully, in the Southern Japanese cities where our programs take place, life was proceeding with power, basic facilities, and transportation all running normally. The personnel at the schools, as well as our own Resident Faculty Director, advised staying put and going to classes, none of which were cancelled. The power plant is in Northeast Japan, and our students were much farther south. Our students communicated with family and friends through social media and their own blogs, and they wanted to remain. In effect, every local contact advised against evacuation. Despite the firsthand evidence, the then chancellor with her own management team directed students to return home. In retrospect, all parties probably recognize that the chancellor's office responded precipitously and that more effective shared governance would have led the administration to make a different decision.

Since 2011, decisions made under the model of shared governance have been more positive for the students. Our networking systems operated smoothly when the November 2015 Paris bombings occurred and the decision was collaboratively made to continue the program. Students were mentored through the experience and learned valuable lessons. Remaining in the city where the attacks took place, our students discussed the responses of people in Paris and how the community carried on. Because our Resident Faculty Director followed protocols, the experiential learning from the terrible events led to discussions about social justice, social inequality, race, ethnic relations, and terrorism. The discussions also encompassed dimensions that the students aren't likely ever to experience again in such a direct and proximate way (see Gleye for his experience during the Brussels tragedy in 2016).

A second area of concern posed for a Study Abroad program within an increasing corporatized university system involves the issue of academic standing. If a study abroad unit loses its academic place in the structural plan and is 
seen as a student service, its connections with faculty are likely to be weak. The lesson for all Study Abroad directors is that they may need to negotiate hard to gain, and then to keep, their central place in the organization chart. Because members of my staff have advanced degrees and faculty status, we belong to both the Faculty Senate and the union that represents faculty. We participate in university committees such as Academic Planning and Policies. I was Secretary of the Faculty Senate from 2015 to 2017 as well as a member of its Executive Committee; I am an active member of the faculty union and was elected to its Executive Board for over six years. I serve on Faculty and Personnel, and Tenure and Review Committees. In other words, we maintain our credibility with faculty and are actively seen as colleagues. This credibility keeps faculty involvement in our programs high.

Instructors, chairs, and former deans serve on the Study Abroad Council, and many of them have mentored and taught students on semesters abroad. Having effective Resident Directors at our host sites is an imperative. There are many reasons for this. In the area of student safety, they are the first line of contact with us, and they are aware of the location and condition of every student. They attend the same twelve-hour cross-cultural and risk management sessions as the students and separate sessions as well. Leading up to their resident directorship, they apply and compete for the position, proposing relevant and creative syllabi and excursions, narrative statements, research projects, and plans for recruitment. I meet individually with all the professors to be sure they understand the extent of their broad responsibilities.

\section{Conclusion}

Studying abroad is an academic endeavor. While senior international officers may want to use third-party providers or other means of sending students without home-institution representatives, that practice is often based on corporate, not academic, models. It requires outsourcing, "the business practice of hiring a party outside a company to perform services and create goods that traditionally were performed in-house by the company's own employees and staff" (Twin 2019). Indeed, freeing the home institution from many responsibilities is the raison d'être of third-party providers. But the raison d'être of universities is, in fact, just that, overseeing academics. Wherever students physically take their courses, they are not a resource for outsourcing, and their studying is neither a co-curricular activity nor primarily a money-making project. Rather, it should be seen as an investment in our students and ultimately in the

public good. Study Abroad is the responsibility of all members of a university. If we believe that curricula and teaching are the purview of faculty and the home institution, then courses taught abroad should always be the outcome of practical and thoughtful shared faculty governance.

\section{References}

"About the University." https://www.hawaii.edu/about-uh/. Last modified, January 23, 2019.

Annual Financial Report, Required Supplementary Information and Other Supplementary Information University of Hawai'i State of Hawai'i http:/www.hawaii.edu/wp/wp-content/uploads/docs/budget-finance/2019-consolidatedfinancial-statements.pdf. December 5, 2019.p. 4

Appendix 2. 1990. "Getting on with the Task," Report on the National Task Force on Undergraduate Education Abroad. In NAFSA's Guide to Education Abroad for Advisers and Administrators, edited William W. Hoffa, John Pearson, and Marvin Slind, 261-83. Washington, DC: NAFSA: Association of International Educators.

Bahls, Steven C. 2017. "From Shared Governance to Shared Accountability." In Shared Governance in Higher Education, Volume 2: New Paradigms, Evolving Perspectives, edited by Sharon F. Cramer, 83-120. Albany: SUNY Press. 
Board of Regents, The University of Hawai'i. Documents (RP 9.) (B 202 p. 3-7) (p. 13, EP 5.221 (1-22). www.hawaii.edu/policy/docs/temp/rp9.202.pdf, 2018.

Bok, Derek. 2004. Universities in the Marketplace: The Commercialization of Higher Education. Princeton, NJ: Princeton Univ. Press.

Cramer, Sharon F., ed. 2017. Shared Governance in Higher Education, Volume 2: New Paradigms, Evolving Perspectives. Albany: SUNY Press.

Deardorff, Darla K., Hans de Wit, John D. Heyl, and Tony Adams, eds. 2012. The Sage Handbook of International Higher Education. Thousand Oaks, CA: Sage.

Deemer, Rob and Virginia Horvath. 2017. "Shared Governance-From Both Sides of the Fence." In Shared Governance in Higher Education, Volume 2: New Paradigms, Evolving Perspectives, edited by Sharon F. Cramer, 21-35. Albany: SUNY Press.

DeWinter, Urbain J. and Laura E. Rumbley. 2010. "The Diversification of Education Abroad Across the Curriculum." In A History of U.S. Study Abroad: 1965-Present, edited by William W. Hoffa and Stephen C. DePaul, 55-106. Lancaster: Whitmore Printing.

DeYoung, Paul and Paul Primak. 1993.“The Education Abroad Office in Its Campus Office.” In NAFSA's Guide to Education Abroad for Advisers and Administrators, edited by William Hoffa, John Pearson, and Marvin Slind, 1726. Washington DC: NAFSA Association of International Educators.

Eaton, Charlie, Adam Goldstein, Jacob Habinek, Mukul Kumar, Tamera Lee Stover andAlex Roehrkasse. 2013. "Bankers in the Ivory Tower: The Financialization of Governance at the University of California" www.irle.berkeley.edu/files/2013/Bankers-in-the-Ivory-Towers.pdf. IRLE Working Paper No. 151-13.

Ehrenberg, R. G. 2000. Tuition Rising. Cambridge, MA: Harvard University Press.

Fuchs, Miriam, Sarita Rai with Yves Loiseau, eds. 2019. Study Abroad: Traditions and New Directions. New York: Modern Language Association.

Gerber, Larry G. 2004. The Rise \& Decline of Faculty Governance: Professionalization and the Modern American University. Baltimore: Johns Hopkins University Press.

Giedt, Todd, Gigi Gokcek, and Jayati Ghosh. 2015. "International Education in the 21st Century: The Importance of Faculty in Developing Study Abroad Research Opportunities." Frontiers: The Interdisciplinary Journal of Study Abroad 26 (Fall): 167-86. https://frontiersjournal.org/past-volumes/volume-xxvi/.

Gleye, Paul. 2017. "Study Abroad in a Time of Terror: U.S. Student Experiences in Brussels." Frontiers: The Journal of Study Abroad 29.1 (April): 5-27. https://frontiersjournal.org/wp-content/uploads/2017/04/XXIX-1-GLEYEStudyAbroadinaTimeofTerror.pdf

Gose, Ben. 2018. "Want More Students to Study Abroad? Get the Faculty Involved." The Chronicle of Higher Education, October 21, 2018. (n.p.)

Hoffa, William W. and Stephen C. DePaul, eds. 2010. A History of U.S. Study Abroad: 1965 to The Present. Special Publication of Frontiers: The Interdisciplinary Journal of Study Abroad. Lancaster: Forum on Education Abroad.

Hoffa, William W., John Pearson, and Marvin Slind, eds. 1993. NAFSA's Guide to Education Abroad for Advisers and Administrators. Washington DC: NAFSA: Association of International Educators.

Interorganizational Task Force on Safety \& Responsibility in Study Abroad. 2002. Responsible Study Abroad: Good Practices for Health and Safety. Washington DC. NAFSA: Association of International Educators.

Krawutschke, Eleanore and Kathleen Sideli. 1993. "Academic Credit." In NAFSA's Guide to Education Abroad for Advisers and Administrators, edited William W. Hoffa, John Pearson, and Marvin Slind, 27-38. Washington DC: NAFSA: Association of International Educators.

"Leading Institutions by Study Abroad Total." 2018. www.iie.org/Research-and-Insights/Open-Doors/Data/US-StudyAbroad/Leading-Institutions." 
Malveaux, Gregory F. 2016. Look Before Leaping: Risks, Liabilities, and Repair of Study Abroad in Higher Education. London: Rowman \& Littlefield.

Martin, Patricia C., ed. 2017. Crisis Management for Education Abroad. NAFSA: Association of International Educators.

Morgenstern, Melissa. 2018. "How to Deal with Depression While Studying Abroad." Blog, July 10, 2018 https://www.gooverseas.com/user/14169

Olson, Gary A. 2009. "What Exactly Is 'Shared Governance'?” Chronicle of Higher Education, 23 July 2009. https://www.chronicle.com/article/exactly-what-is-shared/4706.

Rai, Sarita. 2019 "Emerging Issues in Study Abroad." In Study Abroad: Traditions and New Directions, edited by Miriam Fuchs, Sarita Rai, with Yves Loiseau, 144-156. New York. Modern Language Association.

Rhodes, Gary, Ludeman, Lindemann, et. al. 2012. "Legal, Health, and Safety Issues: Crisis Management and Student Services in International Education.” In Deardorff, de Witt, Heyl, and Adams 2012, 223-41. http://dx.doi.org/10.4135/9781452218397.n13

Russel, Dominic, Carrie Sloan, and Alan Smith. 2016. "The Financialization of Higher Education: What Swaps Cost Our Schools and Students." The Roosevelt Institute, June 2016. 3-46. http://rooseveltinstitute.org/wpcontent/uploads/2016/09/Financialization-of-Higher-Education.pdf.

Slaughter, S. and Leslie, L. L. 1997. Academic Capitalism: Politics, Policies, and the Entrepreneurial University. Baltimore, MD: Johns Hopkins University Press.

Seltzer, Rick. 2018. "State Support of Higher Education Grows 16 Percent.” Inside Higher Ed, January 22, 2018. http://www.insidehighered.com/news/2018/01/22/state-support-higher-ed-grows-16-percent-2018.

Twin, Alexandra. “Outsourcing." Investopedia, June 25, 2019. https://www.investopedia.com/terms/o/outsourcing.asp

Torralba, Jose A. 2019 "Developing a Service-Learning Component within a University-Based Study Abroad Program: Implications for University-Community Relations." In Study Abroad: Traditions and New Directions, edited by Miriam Fuchs, Sarita Rai, with Yves Loiseau, 55-62. New York. Modern Language Association.

Woodhouse, Kellie. 2015. "Money Talk." Inside Higher Ed, April 28, 2015.

https://www.insidehighered.com/news/2015/04/28/communication-issue-college-administrators-and-faculty duringera-financial-change 